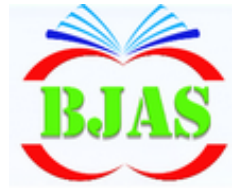

ISSN 1814 - 5868
Available online at http://bjas.bajas.edu.iq https://doi.org/10.37077/25200860.2020.33.1.09 College of Agriculture, University of Basrah

Basrah J. Agric. Sci. 33(1): 107-121, 2020
Basrah Journal of Agricultural Sciences

E-ISSN: 2520-0860

\title{
Genetic and Phenotypic Assessment of Garden Peas (Pisum sativum L.) Genotypes
}

\author{
Slavka Kalapchieva ${ }^{1}$, Valentin $\operatorname{Kosev}^{2}$ \& Viliana Vasileva ${ }^{2 *}$ \\ ${ }^{1}$ Maritsa Vegetable Crops Research Institute, 32 Brezovsko shosse Str., 4003 Plovdiv, Bulgaria \\ ${ }^{2}$ Institute of Forage Crops, 89 General Vladimir Vazov Str., 5800 Pleven, Bulgaria \\ *Corresponding author: viliana.vasileva@gmail.com
}

Received 17 March 2020; Accepted 29 April 2020; Available online 27 June 2020

\begin{abstract}
The field trial was conducted during the growing season 2017-2019 in the experimental fields of the Maritsa Vegetable Crop Institute, Plovdiv, Bulgaria. The study used 10 samples of garden peas (Pisum sativum L). for measurement. Plant tall $(\mathrm{cm})$, height to first fertile node $(\mathrm{cm})$, length of internode $(\mathrm{cm})$, number of tillers, number of branches, number of ineffective nodes, total number of nodes, total number of pods per plant, one pod per fruiting handle, two pods per fruiting handle, pod length $(\mathrm{cm})$, pod width $(\mathrm{cm})$, pod weight per plant, weight of green grains per plant (g), \% filled grains, \% unfilled grains, average number of grains per pod were assessed. Analysis variance showed significant differences between the genotypes of garden peas in all the traits studied. A lower level of the genetic variance was found compared to the phenotypic one by the number of branches, total number of nodes and one pod per fruiting handle. The coefficient of genetic variation is higher than the phenotypic one for most of the traits and ranged from $5.51-5.82 \%$ for pod width and total number of nodes to 56.98-59.09\% for number of branches and \% unfilled grains. For signs of plant tall $(98.32 \%$ and $129.31 \%)$, height to first fertile node $(91.22 \%$ and $29.32 \%$ ), weight of pods per plant $(86.83 \%, 29.32)$, weight of green grains per plant $(83.7 \%, 11.89 \%)$ and $\%$ filled grains $(77.81 \%$ and $24.96 \%)$. It was found high inheritance combined with high genetic progress. This is a prerequisite for increasing the biological potential on these traits and a real opportunity to create new forms of garden peas possessing such qualities. The best genotypes were found GEN 1 (22/16-n.), GEN 6 (Marsy-n.), GEN 4 (Plovdiv-n.) and GEN 9 (1/17-n.). They may be used in new breeding programs and hybrid lines may be entered in competitive variety lists.
\end{abstract}

Key words: Garden pea, Genotypes, Breeding, inheritance, Breeding.

\section{Introduction}

Pea (Pisum sativum L.) is the second of the most important legume crops for grain production in the world after dry bean. Grain of pea has high level protein, amino acids, minerals and vitamins and it is used for canning or baking. Pea is also an important grain legume for crop rotation because of providing nitrogen and organic matter to the soil (Ton et al., 2018). For any breeding program, genetic variability plays an important role as it provides opportunity to plant breeders for selection of 


\section{Kalapchieva et al. / Basrah J. Agric. Sci., 33(1): 107-121, 2020}

high yielding genotypes (Bashir et al., 2017). To improve the genetic contents for any crops, genetic variability is a prerequisite for crop improvement program. For the exploitation of the desirable traits for enhancing the yield in peas, both, the nature and magnitude of genetic variability and extent to which the desirable traits were heritable are important. Genetic variability has been considered as an important factor, which is also an essential prerequisite for crop improvement program for obtaining high yielding progenies. Evaluation of genetic variability is important to know the source of genes for a particular trait within the available germplasm (Tiwari \& Lavanya, 2012; Saddika et al., 2013; Tamene, 2017).

Estimating the parameters of variability, especially heritability and genetic gain are important indicators for improvement of traits through selection whereas the selection for highly heritable characters is more effective. Therefore, heritability along with other parameters of variability can be used in predicting the gain for a given selection intensity and expected genetic gain further gives the idea of the extent of improvement in a traits through simple selection (Yumkhaibam et al., 2019).

A broad choice of variability in any crop always gives the good chances of selecting desired types which could be utilized in breeding. Heritability is the segment of phenotypic variation which is transmitted from parent to progeny. The higher the heritable difference, the superior will be the opportunity of fixing the character by selection methods (Ullah et al., 2019). Genetic variability within tested genotypes and knowledge about it offers a basis for improvement and developing new cultivars (Milenković et al., 2017).

Selection aimed at improving the varietal structure of crops is determined by the variety of germplasm available. The broad genetic base makes it possible to select genotypes with desirable traits which will be used as an initial material in the selection process.

The purpose of the study was to evaluate the genetic diversity of a collection of garden pea samples for the purposes of combinational selection.

\section{Materials \& Methods}

The study was conducted during the growing season 2017-2019 in the experimental fields of the Maritsa Vegetable Crop Institute, Plovdiv, Bulgaria with ten genotypes of garden peas GEN 1 (22/16-n.), GEN 2 (22/16-af.), GEN 3 (Casino-af.), GEN 4 (Plovdiv-n.), GEN 5 (Echo-af.), GEN 6 (Marsy-n.), GEN 7 (Shugar duarf-n.), GEN 8 (B4-34- n.), GEN 9 (1/17-n.), and GEN 10 (Vechernitza-n). The experiment was based on four replicates by RCBD design with a working plot area of $6.4 \mathrm{~m} 2$. The sowing was done at the end of February on a high flatbed according to the scheme high flat bed at $80 \mathrm{~cm}$ between the beds, on the bed itself the distances between the rows are $20 \mathrm{~cm}-40 \mathrm{~cm}$ and $20 \mathrm{~cm}$. Peas were grown according to the technology of growing of this crop.

The basic morphological (biometric) characteristics of the aboveground organs were measured at the technical maturity of 10 plants per each replication: plant tall $(\mathrm{cm})$, height to first fertile node $(\mathrm{cm})$, length of internode $(\mathrm{cm})$, number of tillers, number of branches, number of ineffective nodes, total number of nodes, total number of pods per 


\section{Kalapchieva et al. / Basrah J. Agric. Sci., 33(1): 107-121, 2020}

plant, one pod per fruiting handle, two pods per fruiting handle, pod length $(\mathrm{cm})$, pod width $(\mathrm{cm})$, pods weight per plant, weight of green grains per plant (g), \% filled grains, \% unfilled grains, average number of grains per pod.

The following statistical methods were used to process the experimental data: analysis of variance, factor analysis by the method of principal components (Vandev, 2003), hierarchical cluster analysis by the method of Ward (1963) - for grouping genotypes based on similarity as a measure of differences (the genetic distance), the Euclidean distance between them was calculated (as a measure for divergence) as the data were standardized preliminary. GGE biplot model was done, which uses singular value decomposition of first two principal components (Yan \& Rajcan, 2002). Genetic advance in absolute unit (GA) and genetic gain (GG), assuming selection of the superior $5 \%$ of the genotypes, were estimated in accordance with the methods illustrated by Johnson et al. (1995). MS Excel (2003) and GENES 2009.7.0 for Windows XP (Cruz, 2009) were used in the processing of experimental data.

\section{Results}

\section{Analysis of variance}

The analysis of the variance and the values obtained for the mean sum of squares of the studied parameters were presented in table (1). The presence of significant differences showed that a comparison between the average values of the parameters of these garden pea samples would be corrected (Table 2). The influence of factor year is stronger for the signs total number of pods per plant, two pods per fruiting handle, while for other indicators the factor is the genotype one. The information obtained in the study on the influence of sources of variation and on the statistically significant differences found for many of the characteristics of garden pea samples confirms the results of the studies of Ahmad et al. (2014), Katiyar et al. (2014) and Saxesena et al. (2014), who report significant morphological differences between their pea samples in terms of basic quantitative and qualitative indicators.

Results similar to those obtained in this study have been reported by Katoch et al. (2016), Kumar et al. (2017) found significant differences in most quantitative traits in pea samples (such as plant tall, number of node per plant, number of effective node per plant, pod bearing length, number of pod per plant, number of effective pod per plant, pod length, seed number per pod, seed number per plant, 100 seed weight, biological yield per plant).

Our findings confirm earlier findings by Lokesh et al. (2018) who report similar results obtained in the evaluation of genetic diversity in 60 pea samples on 23 traits. 
Kalapchieva et al. / Basrah J. Agric. Sci., 33(1): 107-121, 2020

Table (1): Analysis of variance.

\begin{tabular}{lccc}
\hline \multicolumn{4}{c}{ Source of variation } \\
\hline Traits & Year & Genotype & Residuo \\
\hline $\mathrm{x} 1$ & 396.2703 & $616.8167^{* *}$ & 10.3769 \\
\hline $\mathrm{x} 2$ & 141.376 & $192.3037^{* *}$ & 16.8804 \\
\hline $\mathrm{x} 3$ & 0.1563 & $4.6945^{* *}$ & 0.1312 \\
\hline $\mathrm{x} 4$ & 0.0555 & $0.5002^{* *}$ & 0.0683 \\
\hline $\mathrm{x} 5$ & 0.0023 & $0.7546^{*}$ & 0.2126 \\
\hline $\mathrm{x} 6$ & 0.0360 & $5.0863^{* *}$ & 0.5854 \\
\hline $\mathrm{x} 7$ & 0.0090 & $4.6797^{* *}$ & 1.2273 \\
\hline $\mathrm{x} 8$ & 13.8063 & $12.9671^{* *}$ & 2.1979 \\
\hline $\mathrm{x} 9$ & 1.1902 & $1.4024^{* *}$ & 0.3975 \\
\hline $\mathrm{x} 10$ & 5.1840 & $2.432^{* *}$ & 0.5018 \\
\hline $\mathrm{x} 11$ & 0.0062 & $0.823^{* *}$ & 0.0293 \\
\hline $\mathrm{x} 12$ & 0.0757 & $0.0156^{* *}$ & 0.0035 \\
\hline $\mathrm{x} 13$ & 83.2496 & $318.3921^{* *}$ & 41.9244 \\
\hline $\mathrm{x} 14$ & 17.2397 & $69.8152^{* *}$ & 11.3800 \\
\hline $\mathrm{x} 15$ & 177.9448 & $484.4233^{* *}$ & 107.5088 \\
\hline $\mathrm{x} 16$ & 178.0207 & $484.4745^{* *}$ & 107.4926 \\
\hline $\mathrm{x} 17$ & 0.0360 & $2.3420^{* *}$ & 0.0738 \\
\hline & & &
\end{tabular}

** and * significant at $1 \%$ and $5 \%$ probability levels, respectively by $\mathrm{F}$ test, $\mathrm{x} 1$ - plant tall, $\mathrm{x} 2$ - height to first fertile node, $x 3$ - length of internode, $x 4$ - number of tillers, $x 5$ - number of branches, $x 6$ - number of ineffective nodes, $x 7$ total number of nodes, $x 8$ - total number of pods per plant, $x 9$ - one pod per fruiting handle, $x 10$ - two pods per fruiting handle, x11 - pod length, x12 - pod width, x13 - pod weight per plant; x14 - weight of green grains per plant; x15 - \% filled grains, x16 - \% unfilled grains, x17 - average number of grains per pod.

\section{Genetic parameters}

The assessment of genetic and phenotypic parameters was presented in table (3). The values of the genetic variance for almost all traits were higher than the corresponding phenotypic variance, such as differences in pod width, number of branches, total number of nodes and number of pods per fruiting handle is smaller than the differences in the other indicators. Genotype variance values ranged from 0.004 for pod width to 202.14 for plant tall.

The genotype variance was relatively low in number of tillers, number of branches, one pod per fruiting handle, two pods per fruiting handle, pod length, and average number of grains per pod, its numerical value not exceeding one. The highest phenotypic variance was characterized by $\%$ filled grains and \% unfilled grains $(107.50,107.49)$, and by the weight of pods per plant (41.92). With a minimal phenotypic variance were pod width, pod length, number of tillers and average number of grains in pod, 0.003, 0.02, 0.06 and 0.07 respectively. This indicates that the $\%$ filled grains, $\%$ unfilled grains, and the weights of pods per plant were signed that were strongly influenced by the environment. 
Kalapchieva et al. / Basrah J. Agric. Sci., 33(1): 107-121, 2020

Table (2): Morphological characteristics of garden pea genotypes.

\begin{tabular}{|c|c|c|c|c|c|c|c|c|c|}
\hline & $\mathrm{x} 1$ & $\mathrm{x} 2$ & $\mathrm{x} 3$ & $\mathrm{x} 4$ & $\times 5$ & $x 6$ & $\mathrm{x} 7$ & $\mathrm{x} 8$ & $\times 9$ \\
\hline GEN 1 & 64.30 & 31.50 & 5.13 & 0.60 & 1.55 & 12.05 & 18.25 & 11.80 & 2.80 \\
\hline GEN 2 & 60.65 & 40.25 & 4.10 & 0.26 & 0.95 & 14.00 & 19.85 & 10.55 & 3.45 \\
\hline GEN 3 & 58.85 & 38.50 & 4.48 & 0.40 & 0.40 & 14.00 & 19.60 & 10.00 & 2.80 \\
\hline GEN 4 & 62.95 & 30.80 & 5.15 & 1.15 & 0.30 & 10.65 & 18.45 & 12.70 & 4.50 \\
\hline GEN 5 & 59.45 & 29.90 & 4.90 & 0.55 & 0.85 & 12.20 & 18.55 & 12.65 & 3.15 \\
\hline GEN 6 & 76.30 & 46.40 & 4.95 & 0.90 & 0.50 & 12.70 & 19.95 & 15.60 & 3.50 \\
\hline GEN 7 & 48.20 & 27.05 & 3.45 & 1.10 & 0.56 & 10.00 & 15.75 & 14.20 & 4.50 \\
\hline GEN 8 & 101.20 & 49.55 & 7.95 & 0.80 & 0.65 & 11.80 & 18.20 & 14.20 & 3.40 \\
\hline GEN 9 & 60.10 & 44.60 & 4.48 & 0.85 & 0.11 & 12.90 & 17.40 & 9.10 & 2.50 \\
\hline GEN 10 & 61.15 & 44.75 & 3.63 & 1.65 & 1.60 & 13.10 & 18.40 & 10.95 & 2.95 \\
\hline $\mathrm{LSD}_{0.05}$ & 5.52 & 7.04 & 0.62 & 0.44 & 0.79 & 1.31 & 1.90 & 2.54 & 1.08 \\
\hline $\mathrm{LSD}_{0.01}$ & 7.57 & 9.65 & 0.85 & 0.61 & 1.08 & 1.79 & 2.60 & 3.48 & 1.48 \\
\hline \multirow[t]{2}{*}{$\mathrm{LSD}_{0.001}$} & 10.31 & 13.15 & 1.16 & 0.83 & 1.47 & 2.45 & 3.54 & 4.74 & 2.01 \\
\hline & $\mathrm{x} 10$ & $\mathrm{x} 11$ & $\mathrm{x} 12$ & $\mathrm{x} 13$ & $\mathrm{x} 14$ & $\mathrm{x} 15$ & $\mathrm{x} 16$ & $\mathrm{x} 17$ & \\
\hline GEN 1 & 4.50 & 7.53 & 1.26 & 39.95 & 16.45 & 77.55 & 22.45 & 5.05 & \\
\hline GEN 2 & 3.55 & 7.05 & 1.12 & 26.21 & 10.67 & 80.94 & 19.06 & 4.85 & \\
\hline GEN 3 & 3.60 & 7.25 & 1.18 & 27.50 & 11.45 & 80.40 & 19.60 & 5.20 & \\
\hline GEN 4 & 4.10 & 6.28 & 1.12 & 38.36 & 19.01 & 91.99 & 8.00 & 5.50 & \\
\hline GEN 5 & 4.75 & 6.73 & 1.07 & 25.60 & 11.81 & 85.82 & 14.18 & 4.55 & \\
\hline GEN 6 & 6.05 & 8.20 & 1.15 & 59.30 & 26.54 & 48.16 & 51.84 & 6.70 & \\
\hline GEN 7 & 5.10 & 6.90 & 1.26 & 32.00 & 13.83 & 86.35 & 13.65 & 6.20 & \\
\hline GEN 8 & 5.35 & 7.45 & 1.22 & 37.40 & 13.42 & 81.48 & 18.52 & 6.55 & \\
\hline GEN 9 & 3.20 & 7.53 & 1.15 & 28.45 & 14.72 & 94.63 & 5.37 & 6.90 & \\
\hline GEN 10 & 4.00 & 7.20 & 1.06 & 27.58 & 11.44 & 82.94 & 17.06 & 6.70 & \\
\hline $\mathrm{LSD}_{0.05}$ & 1.21 & 0.29 & 0.10 & 11.10 & 5.78 & 17.78 & 17.79 & 0.46 & \\
\hline $\mathrm{LSD}_{0.01}$ & 1.66 & 0.40 & 0.13 & 15.21 & 7.92 & 24.36 & 24.36 & 0.63 & \\
\hline $\mathrm{LSD}_{0.001}$ & 2.26 & 0.54 & 0.18 & 20.73 & 10.80 & 33.20 & 33.19 & 0.86 & \\
\hline
\end{tabular}

x1 - plant tall, x2 - height to first fertile node, x3 - length of internode, $x 4$ - number of tillers, $x 5$ - number of branches, $x 6$ - number of ineffective nodes, $x 7$ - total number of nodes, $x 8$ - total number of pods per plant, $x 9$ - One pod per fruiting handle, x10 - Two pods per fruiting handle, x11 - pod length, x12 - pod width, x13 - pod weight per plant; x14 - weight of green grains per plant; x15 - \% filled grains, x16 - \% unfilled grains, x17 - average number of grains per pod GEN 1 (22/16-n.), GEN 2 (22/16-af.), GEN 3 (Casino-af.), GEN 4 (Plovdiv-n.), GEN 5 (Echo-af.), GEN 6 (Marsy-n.), GEN 7 (Shugar duarf-n.), GEN 8 (B4-34- n.), GEN 9 (1/17-n.), GEN 10 (Vechernitzan).

\section{Phenotypic and genotypic coefficient of variation}

The genotypic coefficient of variation (GCV) is an indicator of experimental precision and also it is part of the assessment of genetic variability. The calculated genotypic coefficients of variation for the different traits studied were shown in table (3). GCV ranged from $5.51-5.82 \%$ for pods width and total number of nodes to $56.98-59.09 \%$, respectively for number of branches and \% unfilled grains. The relative GCV values for pod length and the 


\section{Kalapchieva et al. / Basrah J. Agric. Sci., 33(1): 107-121, 2020}

number of ineffective nodes indicated that their variation was also very low $(7.13 \%, 9.93 \%)$. On the other hand, the genotypic variation coefficient $(\mathrm{GCV}, \%)$ was higher for a significant part of the traits studied (excepting number of branches, total number of nodes, one pod per fruiting handle). The genotypic coefficient of variation was greater than the phenotypic coefficient of variation. The ratio of GCV to CVP in these was greater than 1. Among the studied indicators, there was a relatively small difference between GCV and CVP for total number of nodes, one pod per fruiting handle, two pods per fruiting handle, pod width and \% filled grains. This indicates that the variation observed was mainly due to genetic factors.

High values of the genotype coefficient of variation have also been reported by Jaiswal et al. (2015). They observed for high genotypic and phenotypic coefficient of variation for plant tall, seed yield per plant and pods per plant in field pea. The authors also report approximately similar magnitude for the same traits and phenotypic coefficient of variation, which is out of sync with our studies.

As a result of their research, Meena et al. (2017) make findings that do not correspond with the present results. They revealed that the relative magnitude of phenotypic coefficients of variation was higher than genotypic coefficients of variation for the characters such as plant height, pod bearing

length, pods per plant and seed yield per plant indicating environmental influence on these traits.

Different from our results are obtained by Lokesh et al. (2018) who report that the phenotypic coefficient of variation was greater than genotypic coefficient of variation for all the traits.

\section{Coefficient of inheritance and Genetic advance}

Inheritance coefficient in a broad sense (H2,\%), based on the sample of garden peas shows high values especially for the signs plant tall (98.32\%), internode length (97.20\%), average number of grains in pods (96.85) \%), pod length $(96.44 \%)$, height to first fertile node $(91.22 \%)$, number of ineffective nodes $(88.49 \%)$ and weight of plant pods $(86.83 \%)$, which was an indication that most of the observed differences are due rather the effect of genetic rather than environmental factors (Table 3).

From the lower inheritance coefficient for the one pod per fruiting handle $(71.66 \%)$, the number of branches $(71.82 \%)$ and the total number of nodes $(73.77 \%)$ it can be assumed that the environment has a greater impact on the phenotypic manifestation of these signs. Similar are the results of the study of Tyagi \& Srivastava (2002). They reported high estimate of genetic advance for characters viz. plant height, pods per plant and biological yield per plant, and also results of Salam et al. (2007). They reported high genetic advance for plant height and pods per plant in field pea.

The experimental data obtained do not confirm the results of some other researchers such as Singh et al. (2011). They reported moderate to high heritability coupled with moderate genetic advance for the characters viz. plant height, pod length and 100 seed weight suggesting the role of additive gene action in the expression of these traits. 
Kalapchieva et al. / Basrah J. Agric. Sci., 33(1): 107-121, 2020

Table (3): Genetic component of variation for quantitative traits in garden pea genotypes.

\begin{tabular}{lccccccccc}
\hline Parameters & $\mathrm{x} 1$ & $\mathrm{x} 2$ & $\mathrm{x} 3$ & $\mathrm{x} 4$ & $\mathrm{x} 5$ & $\mathrm{x} 6$ & $\mathrm{x} 7$ & $\mathrm{x} 8$ & $\mathrm{x} 9$ \\
\hline Min & 41.20 & 20.80 & 3.10 & 0.01 & 0.01 & 9.50 & 14.90 & 7.70 & 1.70 \\
\hline Max & 108.90 & 56.10 & 7.95 & 2.10 & 2.70 & 14.40 & 21.30 & 16.90 & 5.30 \\
\hline Mean & 75.05 & 38.45 & 5.52 & 1.05 & 1.35 & 11.95 & 18.10 & 12.30 & 3.50 \\
\hline StDev & 14.34 & 8.01 & 1.25 & 0.41 & 0.50 & 1.30 & 1.25 & 2.08 & 0.68 \\
\hline GCV $(\%)$ & 21.77 & 19.95 & 25.59 & 45.96 & 56.98 & 9.93 & 5.82 & 15.56 & 17.25 \\
\hline CVP $(\%)$ & 4.94 & 10.73 & 7.53 & 31.70 & 61.93 & 6.21 & 6.00 & 12.16 & 18.75 \\
\hline $\mathrm{V}_{\mathrm{g}}$ & 202.14 & 58.47 & 1.52 & 0.14 & 0.18 & 1.50 & 1.15 & 3.58 & 0.33 \\
\hline $\mathrm{Vp}$ & 10.37 & 16.88 & 0.13 & 0.06 & 0.21 & 0.58 & 1.22 & 2.19 & 0.39 \\
\hline GA & 129.31 & 29.32 & 8.68 & 1.18 & 0.81 & 4.06 & 2.14 & 4.98 & 1.09 \\
\hline GG & 8.84 & 22.01 & 13.44 & 47.83 & 69.67 & 13.13 & 12.57 & 24.78 & 36.76 \\
\hline Herdability $(\%)$ & 98.32 & 91.22 & 97.20 & 86.35 & 71.82 & 88.49 & 73.77 & 83.05 & 71.66 \\
\hline & $\mathrm{x} 10$ & $\mathrm{x} 11$ & $\mathrm{x} 12$ & $\mathrm{x} 13$ & $\mathrm{x} 14$ & $\mathrm{x} 15$ & $\mathrm{x} 16$ & $\mathrm{x} 17$ & \\
\hline Min & 2.20 & 6.25 & 0.97 & 22.60 & 9.52 & 14.84 & 5.20 & 4.40 & \\
\hline Max & 6.90 & 8.45 & 1.43 & 64.19 & 28.98 & 94.80 & 85.16 & 7.20 & \\
\hline Mean & 4.55 & 7.35 & 1.20 & 43.39 & 19.25 & 54.82 & 45.18 & 5.80 & \\
\hline StDev & 0.90 & 0.52 & 0.07 & 10.30 & 4.82 & 12.71 & 12.71 & 0.88 & \\
\hline GCV $(\%)$ & 18.15 & 7.13 & 5.51 & 28.04 & 29.56 & 13.83 & 59.09 & 14.94 & \\
\hline CVP $(\%)$ & 16.06 & 2.38 & 5.10 & 18.95 & 22.56 & 12.81 & 54.71 & 4.67 & \\
\hline$V_{g}$ & 0.64 & 0.26 & 0.004 & 92.15 & 19.47 & 125.63 & 125.66 & 0.75 & \\
\hline Vp & 0.50 & 0.02 & 0.003 & 41.92 & 11.38 & 107.50 & 107.49 & 0.07 & \\
\hline GA & 1.86 & 3.79 & 0.15 & 29.32 & 11.89 & 24.96 & 24.97 & 5.84 & \\
\hline GG & 32.01 & 3.96 & 9.40 & 30.74 & 36.10 & 38.96 & 47.27 & 9.40 & \\
\hline Heritability $(\%)$ & 79.37 & 96.44 & 77.80 & 86.83 & 83.70 & 77.81 & 77.81 & 96.85 & \\
\hline x & & &
\end{tabular}

x1 - plant tall, x2 - height to first fertile node, x3 - length of internode, $x 4$ - number of tillers, $x 5$ - number of branches, $\mathrm{x} 6$ - number of ineffective nodes, $\mathrm{x} 7$ - total number of nodes, $\mathrm{x} 8$ - total number of pods per plant, $\mathrm{x} 9$ - One pod per fruiting handle, x10 - Two pods per fruiting handle, x11 - pod length, x12 - pod width, x13 - pod weight per plant; x14 - weight of green grains per plant; x15 - \% filled grains, x16 - \% unfilled grains, x17 - average number of grains per pod; GCV (\%), genotypic coefficient of variation; CVP (\%), phenotypic coefficient of variation $V_{g}$, genotypic variance; $\mathrm{Vp}$, phenotypic variance; GA, Genetic Advance; GG, Genetic Gain; $\mathbf{H}^{2}(\%)$, broad-sense heritability

The heritability can be enhanced with combined genetic advance. The heritability estimate could be best-utilized in combination with the selection differential in predicting genetic gain following selection process. The value of genetic progress obtained by different selection methods can be used to estimate the expected progress in the selection process (Table 3). The signs of plant tall (129.31), height to first fertile node, weight of plant pods (29.32), \% filled grains (24.96), \% unfilled grains (24.97) and weight of green grains per plant (11.89) show the best and preferred presentation, the others, especially pod width (0.15), number of branches (0.81) and one pod per fruiting handle (1.09) occupy the last positions. The high GG values for traits with higher genetic progression suggest that there is a higher genetic benefit than for indicators with lower such parameters.

From the results obtained, it is clear that a high coefficient of inheritance, combined with 


\section{Kalapchieva et al. / Basrah J. Agric. Sci., 33(1): 107-121, 2020}

medium to high genetic progress, was established for plant tall, height to first fertile node, weight of pods per plant, weight of green grains per plant and \% filled grains. This is a prerequisite for enhancing the biological potential of these traits and a real opportunity to create new genotypes possessing such traits. In the case of combining breeding approaches (such as the application of recurrent reciprocal selection) the expected genetic progress (profit) would be higher than when applying a single method alone. The estimated genetic progression based on the relative values of genetic variability and heredity indicates the breeding progress and efficiency of the method used to identify the promising samples.

\section{Principal component analysis}

If we have more than two factors (PC1, PC2, PC3, etc.) which variation can be distributed, the impact of a given recognition remains nonlinear. With a similar survey of the views we can present, the samples analyzed so that we cannot see them, that we can remain part of those who respond positively or change stable opportunities to recognize you in the opposite direction. This has certainly created some difficulties in assessing the value of genotype release against the background of the group of samples tested.

Table (4) presents data for the applied principal component analysis. Four major components with a unit weight exceeding $80.45 \%$ of the total variation were extracted. The first component was related to the signs of weight of pods per plant, $\%$ of unfilled grains, weight of green grains per plant, two pods per fruiting handle and total number of pods per plant.

The second component determines the variation due to the number of ineffective nodes, the total number of nodes, the height to the first fertile node, and the length of the pods. Genotypes GEN 1 and GEN 6 are characterized by positive values of the first two principal components (Figure 1) (first quadrant). Samples GEN 2, GEN 3, GEN 9 and GEN 10 refer to the quadrant bounded by the negative values of PC1 and the positives of PC2. Their close location within the quadrant gives reason to believe that they are phenotypically very close in some of the studied traits. GEN 8 was located independently in the lower right quadrant of the coordinate system with positive values only on component $\mathrm{PC} 1$. Its projection in the plane shows that by phenotype it was quite different from other samples in many characteristics, but in morphology it was partially similar to GEN 1 and GEN 6. In the lower left quadrant are located GEN 5, GEN 4 and GEN 7. The figure shows that the last two genotypes are relatively close to the negative part of the ordinate axis (PC2), and GEN 5 was located immediately adjacent to the negative part of the abscissa (PC1) near GEN 10 from the adjacent quadrant. This proximity suggests that, despite being located in different quadrants, these specimens have similarities in some traits. 
Kalapchieva et al. / Basrah J. Agric. Sci., 33(1): 107-121, 2020

Table (4): The Eigen values and vectors of the correlation matrix for 17 traits in garden pea genotypes.

\begin{tabular}{lcccc}
\hline Variables & PC1 & PC2 & PC3 & PC4 \\
\hline Plant tall & 0.2665 & 0.0891 & 0.2805 & 0.4020 \\
\hline Height to first fertile node & 0.1876 & 0.3135 & 0.4083 & -0.0111 \\
\hline Length of internode & 0.1854 & 0.0107 & 0.2232 & 0.5795 \\
\hline Number of tillers & 0.0385 & -0.2170 & 0.3531 & -0.4580 \\
\hline Number of branches & -0.0257 & 0.1036 & -0.1259 & -0.1446 \\
\hline Number of ineffective nodes & -0.0345 & 0.4999 & -0.0549 & -0.0622 \\
\hline Total number of nodes & 0.1228 & 0.3720 & -0.2811 & 0.0507 \\
\hline Total number of pods per plant & 0.3094 & -0.2842 & -0.1067 & 0.0671 \\
\hline One pod per fruiting handle & 0.0456 & -0.4200 & -0.1431 & -0.0026 \\
\hline Two pods per fruiting handle & 0.3371 & -0.2048 & -0.0913 & 0.0609 \\
\hline Pod length & 0.2899 & 0.2471 & 0.1178 & -0.1048 \\
\hline Pod width & 0.0949 & -0.1859 & 0.0049 & 0.2834 \\
\hline Pod weight per plant & 0.3811 & -0.0781 & -0.0865 & -0.0743 \\
\hline Weight of green grains per plant & 0.3259 & -0.1051 & -0.0962 & -0.1758 \\
\hline \% filled grains & -0.3562 & -0.1296 & 0.2428 & 0.1513 \\
\hline \% unfilled grains & 0.3561 & 0.1297 & -0.2428 & -0.1513 \\
\hline Average number of grains per pod & 0.1773 & -0.0460 & 0.5417 & -0.2892 \\
\hline Parameter & & & & \\
\hline Variability (\%) & 34.79 & 22.51 & 12.41 & 10.74 \\
\hline Cumulative & 0.3479 & 0.573 & 0.697 & 0.8044 \\
\hline EigenValues & 5.9130 & 3.826 & 2.109 & 1.825 \\
\hline C1; PC2 PC3 PC4 & & & &
\end{tabular}

PC1; PC2; PC3, PC4 = principal component 1, 2, 3 and 4, respectively

The location of the traits in the bipolar plane (Fig. 1) shows that the quantitative indicators studied determine the number of ineffective nodes, $\%$ filled grains, the total number of pods per plant, the one pod per fruiting handle, the weight of pods per plant and two pods per fruiting handle. They are also the longest vectors determining the level of diversity.

The vectors of the signs pods weight the average number of grains in pod and the weight of the green grains from the plant form sharp angles with each other, indicating a strong positive relationship between them. Similar dependencies with the same sign are found between the one pod per fruiting handle and the number of tillers, plant tall and \% unfilled grains, and between the number of branches and the number of unfilled nodes.

When comparing the figures (Fig.1A and Fig. 1B), the similarity of the samples in groups can be judged by certain traits. The closer the projections of the patterns in Figure 1A are to the vectors of the corresponding features in Figure $1 \mathrm{~B}$, the more specific the indicator is decisive in grouping them.

As can be seen from the figures, a certain selection value by weight of green grains per plant was the GEN 5; in terms of length of internodes and average number of grains in pod GEN 8 and in number of branches GEN 10. 
Kalapchieva et al. / Basrah J. Agric. Sci., 33(1): 107-121, 2020

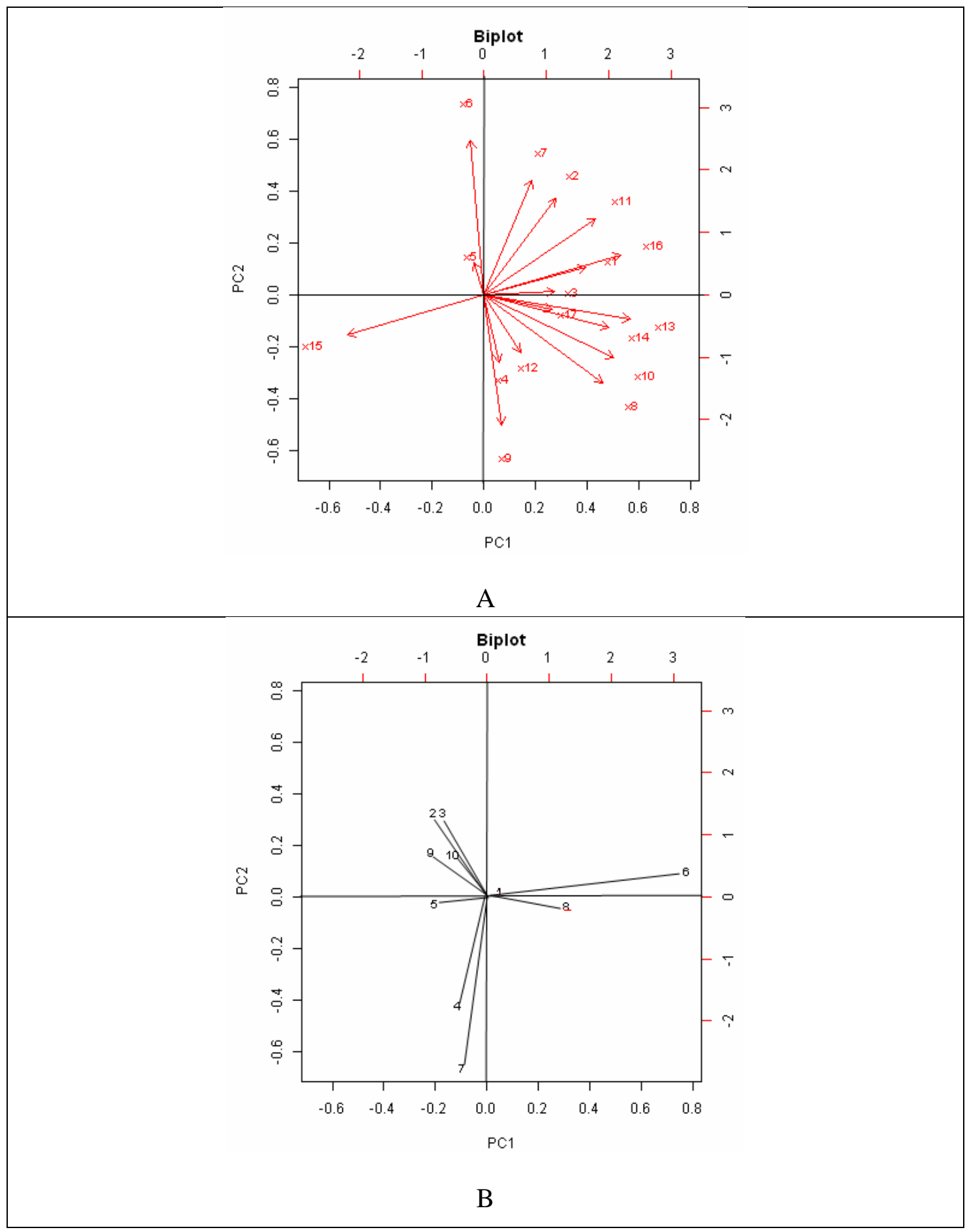

Fig. (1): Projection of the characteristics and varieties of garden peas on a vector plane.

A - traits: x1 - Plant tall, $x 2$ - Height to first fertile node, $x 3$ - Length of internode, $x 4$ - Number of tillers, $x 5$ Number of branches, $x 6$ - Number of ineffective nodes, $x 7$ - Total number of nodes, $x 8$ - Total number of pods per plant, x9 - One pod per fruiting handle, x10 - Two pods per fruiting handle, x11 - pod length, x12 - pod width, x13 - pod weight per plant; x14 - weight of green grains per plant; x15 - \% filled grains, x16 - \% unfilled grains, x17 average number of grains per pod B - genotypes garden pea: 1- GEN 1 (22/16-n.), 2- GEN 2 (22/16-af.), 3 - GEN 3 (Casino-af.), 4 - GEN 4 (Plovdiv-n.), 5 - GEN 5 (Echo-af.), 6 - GEN 6 (Marsy-n.), 7 - GEN 7 (Shugar duarf-n.), 8 GEN 8 (B4-34- n.), 9 - GEN 9 (1/17-n.), 10 - GEN 10 (Vechernitza-n). 


\section{Cluster analysis}

A hierarchical cluster analysis was applied to identify the similarity and proximity of the garden pea samples, and the results of the clustering were presented graphically via a dendrogram (Fig. 2).

The pea genotypes studied differ in the quantitative indicators analyzed and are grouped into two main clusters. The first cluster was the smallest and only GEN 6 was involved in it. It has higher values of the traits as total number of pods per plant, Two pods per fruiting handle, pod length, weight of the pods of the plant, and \% of unfilled grains and with the lowest level of \% filled grains (almost twice compared to other samples). The second cluster includes the other 9 pea genotypes in the collection. This cluster, as a separate subgroup, occupies an individual place GEN 8. The dendrogram shows that this genotype was at a very high level from the first division and, by morphological characteristics, stands very close to GEN 6 and was characterized by higher values for plant tall, height to the first fertile node, two pods per fruiting handle, length and width of pods. In terms of the value of many of the other indicators, it was similar to the other samples and this determines its intermediate position on the dendrogram.

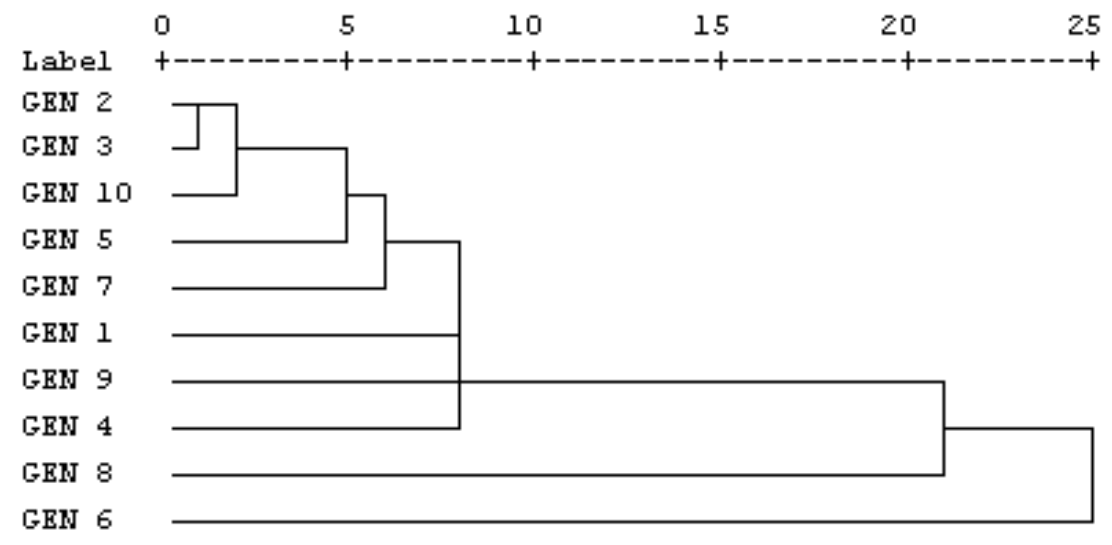

Fig. (2): Dendrogram of genotypes of garden peas (2018-2019).

GEN 1 (22/16-n.), GEN 2 (22/16-af.), GEN 3 (Casino-af.), GEN 4 (Plovdiv-n.), GEN 5 (Echo-af.), GEN 6 (Marsy-n.), GEN 7 (Shugar duarf-n.), GEN 8 (B4-34- n.), GEN 9 (1/17-n.), GEN 10 (Vechernitza-n).

The second subgroup of the arrangement of the samples shows that GEN 1, GEN 10 and GEN 4 are the second subgroup of the arrangement of the samples shows that GEN 1 , GEN 9 and GEN 4 are separated at the midlevel of the original division. They can be considered relatively close in only some traits, such as the number of ineffective nodes, the one pod per fruiting handle, two pods per fruiting handle, $\%$ filled grains, and the average number of grains per pod. Genetically closer are especially the plant tall, length of internodes, total number of nodes, length and width of the pods. Genotypes GEN 5 and GEN 


\section{Kalapchieva et al. / Basrah J. Agric. Sci., 33(1): 107-121, 2020}

7 exhibit some similarity due to the manifestation of the traits height to first fertile node, total number of pods per plant, length and width of pods, filled and unfilled grains. When arranging samples GEN 2, GEN 3 and GEN 10 occupy the uppermost part of the dendrogram. Their position indicates that they are very similar in genotype with similar genetic formulas, which determine the plant tall, the total number of pods per plant, the two pods per fruiting handle, the weight of the pods per plant and weight of green grains per plant, and with satisfactory representation of the number of unproductive nodes, the total number of nodes, and the length of the pods.

A number of studies (Tahernezhad et al., 2010) showed that cluster analysis suggests very well the presence of genetic similarity or distance between genotypes, which is also confirmed by the data obtained in this study. The same authors believe that to obtain a more objective assessment, it is advisable to use different methods to determine the polymorphism of the available genetic plasma.

The results of our study are in agreement with the opinion of other researchers such as Bhandari et al. (2017) who recommend multivariate statistical methods for genetic diversity assessment be applied when analyzing different samples (varieties, lines). According to the authors, these techniques have a very good theoretical basis for providing reliable information about the actual genetic similarity between the different genotypes and can thus be used to determine the extent of genetic diversity.

\section{Conclusions}

The calculating genetic and phenotypic parameters referred to different genetic material of experimental material that responded in a specific way to environmental conditions. Information on the overall phenotypic variation resulting from the joint action of genetic and environmental factors is very important for the breeder to make the right decision using the available genetic resources and to predict future breeding success.

Analysis of variance shows significant differences between the genotypes of garden peas in all the traits studied. A lower level of the genetic variance was found compared to the phenotypic one by number of branches, total number of nodes and one pod per fruiting handle traits. The coefficient of genetic variation is higher than the phenotypic one for most of the traits and ranges from 5.51-5.82\% (for pod width and total number of nodes) to $56.98-59.09 \%$ (for number of branches and \% unfilled grains). The analysis of the variance shows significant differences between the genotypes of garden peas in all the traits studied. For signs of plant height $(98.32 \%$ and 129.31), height to first fertile node $(91.22 \%$ and 29.32 ), weight of pods per plant $(86.83 \%$, 29.32), weight of green grains per plant $(83.7 \%$ and 11.89$)$ and $\%$ filled grains $(77.81 \%$ and 24.96) high inheritance combined with high genetic progress. This is a prerequisite for increasing the biological potential on these traits and a real opportunity to create new forms of garden peas possessing such qualities. The applied hierarchical cluster analysis groups the studied pea genotypes according to the analyzed characteristics into two main clusters. Only the GEN 6 is present in the first cluster, with higher trait values as the traits as total number of pods per plant, two pods per fruiting 
handle, length of pods, weight of pods per plant and $\%$ unfilled grains. The second cluster includes the other 9 pea genotypes in the collection. GEN 1 (22/16-n.), GEN 6 (Marsyn.), GEN 4 (Plovdiv-n.) and GEN 9 (1/17-n.) were found the best genotype for the future breeding programs.

\section{Conflict of interest}

The authors declare that they have no conflict of interest.

\section{Acknowledgements}

The research leading to these results has received funding from the National Science Fund, Bulgaria [Grant КП-06-H26/12].

\section{References}

Ahmad, H.B.; Rauf, S.; Rafiq, Ch.M.; Mohsin, A.U. \& Iqbal, A. (2014). Estimation of genetic variability in pea (Pisum sativum L.). J. Global Innov. Agric. Soc. Sci., 2(2): 6264. https://doi.org/10.17957/JGIASS/2.2.496

Bashir, I.; Ishtiaq, S.; Fiaz, S. \& Sajjad, M. (2017). Association of yield attributing traits in pea (Pisum sativum L.) germplasm. Banatcs J. Biotechnol., 8(15): 43-49. https://doi.org/10.7904/2068-4738-VIII(15)43

Bhandari, H.R.; Nishant Bhanu, A.N.; Srivastava K.; Singh, M.N.; Shreya, \& Hemantaranjan, A. (2017). Assessment of genetic diversity in crop plants - An Overview. Adv. Plants Agric. Res., 7(3): 00255.

https://doi.org/10.15406/apar.2017.07.00255

Cruz, C.D. (2009). Programa Genes: Biometria. version 7.0. Univ. Federal Viçosa, Viçosa, Brazil. http://arquivo.ufv.br/dbg/genes/gdown2.htm

Jaiswal, N.K.; Gupta, A.K.; Dewangan, H. \& Lavanya, G.R. (2015). Genetic variability analysis in field pea (Pisum sativum L.). Int. J. Sci. Res., 4(1): 2006-2007. https://doi.org/10.17221/89/2017-CJGPB

Johnson, H.W.; Robinson, H.F. \& Comstock, R.E. (1995). Estimates of genetic and environmental variability in soya beans. Agron. J., 47: 314-318. https://doi.org/10.2134/agronj1955.0002196 2004700070009x

Katiyar, S.; Singh, H.C.; Verma, M.C.; Katiyar, M. \& Singh, R.K. (2014). Genetic analysis for of heterotic crosses in table pea (Pisum sativum L.). Trends Biosci., 7(9): 733-735. http://trendsinbiosciencesjournal.com/upload /13-777_(Sunil).pdf

Katoch, V., Singh P.; Mayanglambam, B.D.; Sharma, A.; Sharma, G.D. \& Sharma J.K. (2016). Study of genetic variability, character association, path analysis and selection parameters for heterotic recombinant inbred lines of garden peas (Pisum sativum var. Hortense L.) under midhill conditions of Himachal Pradesh, India. Legume Res.; 39(2): 163-169. https://doi.org/10.18805/1r.v0iOF.6775

Kumar, M., Jeberson, M.S., Singh, N.B.\& Sharma, R. (2017). Genetic analysis of seed yield and its contributing traits and pattern their inheritance in field pea (Pisum sativum L). Int. J. Curr. Microbiol. Appl. Sci., 6(6): 172-181.

https://doi.org/10.20546/ijcmas.2017.606.02 1

Lokesh Gour, R.K.; Dubey, P.K.; Moitra, S.K.; Singh, S.S.; Shukla, S. \& Tiwari, S. (2018). Genetic parameters exploration of pea genotypes using two environmental conditions. Int. J. Curr. Microbiol. Appl. Sci., $\quad 7(9)$ : $2067-2078$. https://doi.org/10.20546/ijcmas.2018.709.25 2

Meena, B.L.; Das, S.P.; Meena, S.K.; Kumari, R.; Devi, A.G. \& Devi, H.L. (2017). Assessment of $\mathrm{gcv}, \mathrm{pcv}$, heritability and genetic advance for yield and its components 
in field pea (Pisum sativum L.) Int. J. Curr. Microbiol. Appl. Sci., 6(5): 1025-1033. https://doi.org/10.20546/ijcmas.2017.605.11 1

Milenković, J.; Stanisavljević, R.; Marković, J.; Petrović, M.; Vasić, T.; Andjelković, S. \& Lugić, Z. (2017). Variability of some traits of vetch genotypes originating from different regions. J. Mountain Agric. Balkans, 20(2): 201-210.

https://www.cabdirect.org/cabdirect/abstract/ 20183199946

Patel, S. (2012). Combining ability analysis for yield and its components in field pea (Pisum sativum L.). M. Sc. (Ag.) Thesis, IGKV, Raipur: 102pp. https://krishikosh.egranth.ac.in/handle/1/915 45

Saddika A.; Aminul Islam, A.K.M.; Golam Rasul, M.; Abdul Khaleque Mian, M. \& Ahmed, J.U. (2013). Genetic variability in advanced generations of vegetable pea (Pisum sativum L.). Int. J. Plant Breed., 7(2): 124-128.

https://doi.org/10.3329/bjpbg.v27i1.23972

Salam, J.L.; Kashyap, O.P.; Pandey, R.L.; Nag, S.K. \& Ranjan, S.K. (2007). Analysis of genetic architect of yield and its components in field pea (Pisum sativum L.). Plant Archives, $\quad 7(1)$ : 229-231. http://krishikosh.egranth.ac.in/handle/1/5810 074296

Saxesena, R.R.; Vidyakar, V.; Vishwakarma, M.K.; Yadav, P.S.; Meena, M.L. \& Lal, G.M. (2014). Genetic variability and heritability analysis for some quantitative traits in field pea (Pisum sativum L.). Bioscan 9(2): $\quad$ 895-898. https://www.researchgate.net/publication/29 3490117_GENETIC_VARIABILITY_AND _HERITABILITY_ANALYSIS_FOR_SOM E_QUANTITATIVE_TRAITS_IN_FIELD_ PEA_PISUM_SATIVUM_L

Singh, A.; Singh, S. \& Babu, J.D.P. (2011). Heritability, character association and path analysis studies in early segregating population of field pea (Pisum sativum L. car. Arvense). Int. J. Plant Breed. Genet., 5(1): 86-92. 10.3923/ijpbg.2011.86.92

Tahernezhad, Z.; Zamani M.J.; Solouki, M.; Zahravi, M., Imamjomeh, A.A.; Jafaraghaei, M. \& Bihamta M.R. (2010). Genetic diversity of Iranian Aegilops tauschii Coss. using microsatellite molecular markers and morphological traits. Mol. Biol. Rep. 37: 3413-3420. https://doi.org/10.1007/s11033-009-9931-6.

Tamene, T.T. (2017). Genetic variation, heritability, and advances from selection in elite breeding materials of field pea (Pisum sativum L.) genotypes. Agric. Res. Tech: Open Access J.; 8(4): 555740. https://doi.org/10.19080/ARTOAJ.2017.08.5 55744.

Tiwari, G. \& Lavanya, G.R. (2012). Genetic variability. In: character association and component analysis in F4 generation of field pea (Pisum sativum var. arvense L.). Karnataka J. Agric. Sci., 25(2): 173-175. https://www.semanticscholar.org/paper/Gen etic-variability $\% 2 \mathrm{C}$-character-associationand-in-TiwariLavanya/62d658428d3e1967b6750fe77371f ae847a90608

Ton, A.; Karaköy, T.; Anlarsa, A.E. \& Türkeri, M. (2018). Investigation of grain yield and yield components of some field pea (Pisum sativum L.) genotypes in Mediterranean climate conditions. Legume Res., 41(1): 4147. https://doi.org/10.18805/LR-340.

Tyagi, M.K. \& Srivastava, C.P. (2002). Genetic variability and correlation among yield and yield characters over two environments in pea. Indian J. Agric. Res., 36(1): 53-56. https://www.indianjournals.com/ijor.aspx?ta rget=ijor:ijar2\&volume $=36 \&$ issue $=1 \&$ article $=010$

Ullah, S.; Batool, S.; Mohibullah, M.; Noreen, J.; Khan, M.; Ali, S.; Saddozai, F.S.; Saddozai, H.S. \& Amin, M. (2019). Studies 


\section{Kalapchieva et al. / Basrah J. Agric. Sci., 33(1): 107-121, 2020}

on the variability parameters in pea. J. Genetics Genomics Plant Breed., 3(1): 1722. http://ejggpb.com/uploads/23_pdf.pdf

Vandev, D.L. (2003). Notes on Applied Statistics 1. Sofia University "St. Kliment Ohridski", Sofia, Bulgaria. 92pp. https://www.academia.edu/3056206/Doing_ statistics_and_probability_with_Mathematic a

Ward, J.H. (1963). Hierarchical grouping to optimize an objective function. J. Am. Stat. Assoc., 58: 236-244. https://www.tandfonline.com/doi/abs/10.108 0/01621459.1963.10500845
Yan, W. \& Rajcan, I. (2002). Biplot evaluation of test sites and trait relations of soybean in Ontario. Crop Sci., 42(1): 11-20. https://doi.org/10.2135/cropsci2002.0011

Yumkhaibam, T.; Deo, C.; Ramjan, Md.; Chanu, N.B. \& Semba, S. (2019). Estimation of genetic variability, heritability and genetic advance for yield and its component traits of garden pea (Pisum sativum L.) in North East India. J. Pharmacog. Phytoch., 8, 3: 40344039.

http://www.phytojournal.com/archives/2019/ vol8issue3/PartBH/8-3-590-476.pdf

\section{Pisum sativum L. التقييم الوراثي والمظهري للتراكيب الوراثية للبازلاء الخضراء}

المستخلص: أجريت هذه التجربة خلال موسم الزراعة 2017- 2019 في حقول التجارب في معهد ماريستا لبحوث محاصيل الخضر، بلوفديف، بلغاريا. أختيرت في الدر اسة 10 نباتات من الباز لاء (Pisum sativum L) لقياس طول النبات(سم)، ارتفاع أول

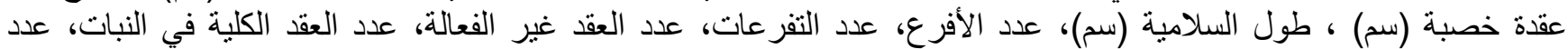

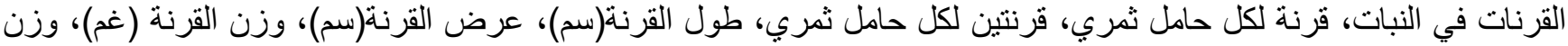

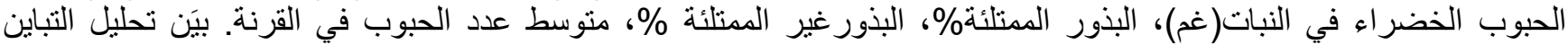

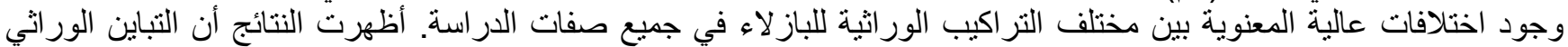

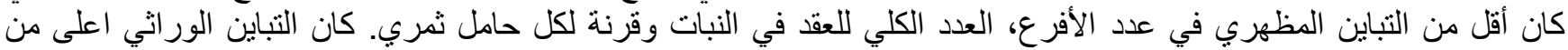

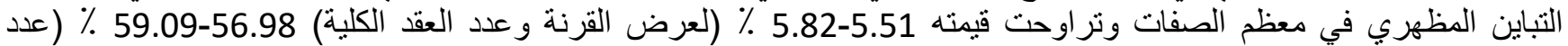

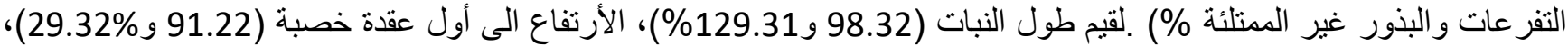

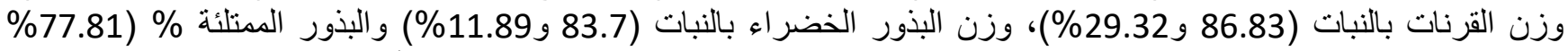

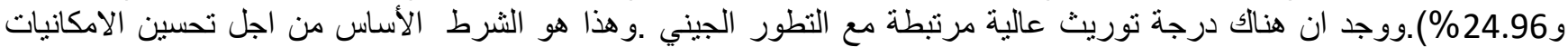

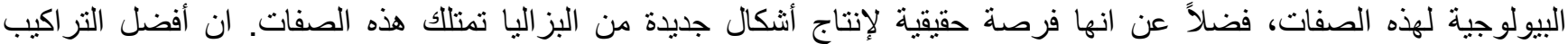

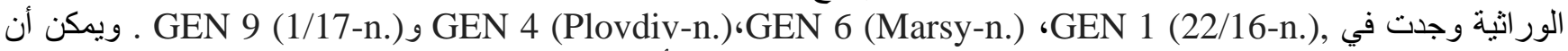
تستخدم في بر امج تربية جديدة في خطوط للتهجين وربما ستدرج في قائمة الأصناف المنافسة. الكلمات المفتاحية: البازلاء الخضراء، تراكيب وراثية، تربية ، توريث. 